\title{
The effect of drying time on the yield and the chemical composition of essential oil and dissolved oil in hydrolat from aerial parts of Moroccan Thymbra capitata (L.) Cav.
}

\author{
Abderrahman Moukhles* and Ahmed Ibn Mansour \\ Laboratory of Applied Organic Chemistry, Department of Chemistry, Faculty of Sciences, Abdelmalek Essaâdi \\ University, M'hanech II, Po Box 2121 Tetouan 93000, Morocco
}

\begin{abstract}
The present research aimed to study the effect of drying time on the yield and chemical composition of essential oil (EO) and dissolved oil in hydrolat (HY) from aerial parts of Moroccan Thymbra capitata (L.) Cav. Drying of plant material was carried out naturally in the shade of a draughty place at room temperature $\left(25-27^{\circ} \mathrm{C}\right)$. A series of 10 plant samples were subjected to hydrodistillation using a Clevenger-type apparatus. The results indicated that the yield of EO increased with drying time to reach the highest value on the $8^{\text {th }}$ drying day $(2.7 \%)$, while the yield of HY has not undergone an apparent variation $(0.2 \%-0.6 \%)$. Based on the GC-MS analyses, EO was composed mainly of the phenolic monoterpene carvacrol $(80.10 \%-92.27 \%)$ along with its biogenetic precursors' monoterpene hydrocarbons in a $1.02 \%-4.81 \%$ range $p$-cymene and $0.24 \%-1.86 \%$ $\gamma$-terpinene. Other essential components occurring in minor quantity were sesquiterpene hydrocarbon $\alpha$-humulene $(2.58 \%-4.67 \%)$ and oxygenated monoterpene linalool $(0.80 \%-2.06 \%)$. At the same time, HY was constituted mainly of carvacrol (94.67-98.42\%) along with $\alpha$-humulene at much lower concentrations $(0.31 \%-0.86 \%)$ and the oxygenated derivative acetovanillone acetate $(0.2 \%-1.80 \%)$. On the other hand, the highest concentration of carvacrol in EO was reached on the $5^{\text {th }}$ day of the drying plant process $(92.27 \%)$, while the HY recovered on the $7^{\text {th }}$ day has shown carvacrol in its highest concentration $(98.42 \%)$.
\end{abstract}

Keywords: Essential oil; hydrolat extract; Thymbra capitata (L.) Cav; drying; GC-MS.

\section{Introduction}

Aromatic and medicinal plants are a source of abundant secondary metabolites such as essential oils, phenolic compounds, and flavonoids, which show different biological effects ${ }^{1-4}$. Several genera of aromatic and Medicinal plants are included in the Lamiaceae family. The thymus is one of these genera represented by more than 200 species everywhere in the world ${ }^{5}$. In Morocco, this genus is represented by 21 species, which 12 are endemic ${ }^{6}$. The thymus is a taxonomically complex group of aromatic plants utilized for medicinal uses or as spices almost everywhere in the world. It is much frequent in the Mediterranean region ${ }^{7-8}$. The thymus is a plant of enormous economic importance, especially in the Mediterranean basin and North America ${ }^{9}$. Essential oils of Thymus have proven its value as a source of bioactive compounds with several biological activities such as antispasmodic ${ }^{10}$, antibacterial ${ }^{11}$, antifungal ${ }^{12-13}$, anti-tabagism ${ }^{14}$, antioxidant ${ }^{11}$, and antimicrobial ${ }^{15}$.

T. capitata (L.) Cav. (formerly Thymus capitatus (L.) Hoffmanns. \& Link) as a Thymus species, is a

*Corresponding author: Abderrahman Moukhles

Email address: mou231073@gmail.com

DOI: http://dx.doi.org/10.13171/mjc10702008061491am
Mediterranean endemic plant ${ }^{16}$. In Morocco, it grows only in the perimeter of Tetouan city (northern Morocco) at a temperate bioclimate ${ }^{6}$. This species is locally known under the vernacular name of "Zaetra" in Moroccan dialect and "Azoukeni" in Tamazight. It commonly used as a food preservative for meat and fish ${ }^{17}$. Furthermore, several studies have reported that $T$. capitata (L.) Cav essential oil possesses different biological and pharmacological activities, such as antibacterial ${ }^{18}$, antimicrobial ${ }^{19}$, antioxidant ${ }^{20-22}$, antifungal ${ }^{23}$, anti-inflammatory ${ }^{1}$, parasiticide $^{21}$, and antispasmodic ${ }^{24}$.

Drying, like dehydration, is a process that eliminates moisture from the plant. The elimination of water from the plant inhibits possible decomposition of phytochemicals and microbial contamination. Most of the drying methods such as air drying, vacuum drying, and oven drying, apply heat on the plant to eliminate the moisture. The increasing drying temperature reduces the drying time by promoting the drying rate. Nevertheless, the employ of high temperature is frequently compromised by the degradation of plant quality ${ }^{25}$. The primary consideration in plants drying is the conservation of 
the phytochemicals, which are often heating sensitive.

Consequently, in the present work, the drying of the studied plant was carried out at room temperature $\left(25-27^{\circ} \mathrm{C}\right)$. Thymus is so perishable, and drying has a beneficial effect, which enhances its storage life for further use. Thus, drying is a conservation method used to ensure the microbial safety of aromatic and medicinal plants. The loss of volatile compounds in aromatic and spice plants depends mainly on drying procedures. Indeed, these compounds, especially terpenes, are the most sensitive ones in the drying process ${ }^{26}$. The drying time also has a significant impact on the qualitative and quantitative composition of aromatic plants' essential oils.
Thus, this work aimed to study the effect of drying time on the yield and the chemical composition of essential oil and hydrolat from aerial parts of Moroccan T. capitata (L.) Cav and the economic benefit of this process.

\section{Results and Discussion}

\subsection{Dehydration kinetics of $\boldsymbol{T}$. capitata (L.) Cav}

The dehydration kinetics of plant material was studied. As shown in Figure 1, a sharp decrease in plant matter weight was noted until the $6^{\text {th }}$ day of the plant drying process. Afterward, no weight loss was observed, confirming the moisture removal from the plant

matter.

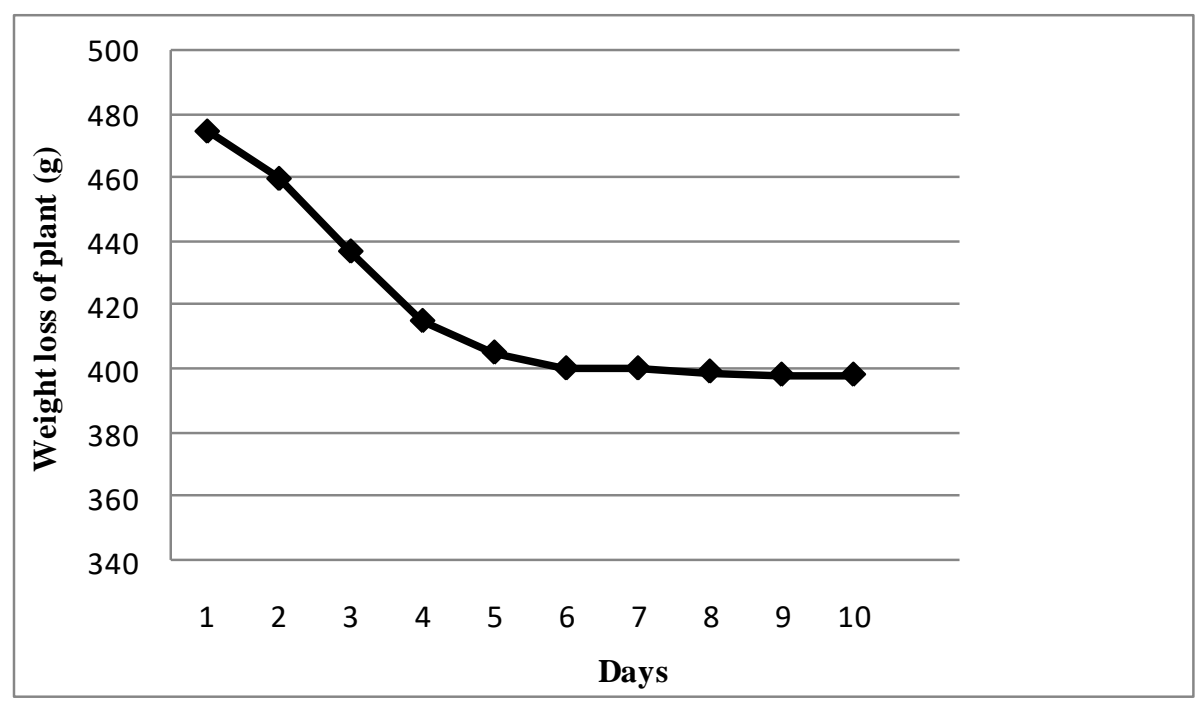

Figure 1. Variation in the weight loss of T. capitata (L.) Cav plant during drying time (Days). Data are the mean of three determinations

\subsection{Evolution of essential oil and dissolved oil in hydrolat yields}

As shown in Figure 2, T. capitata (L.) Cav EO yield was strongly influenced by drying time. Indeed, its value increased to reach a maximum rate of $2.7 \%$ on the $8^{\text {th }}$ day of plant drying and decreased after that. This result is following a study carried out by Bourkhiss et al. (2009) ${ }^{27}$; these researchers found that Tetraclinis articulata (Vahl) Masters essential oil yield increased with drying time to range its maximal value on the $9^{\text {th }}$ day of plant drying and after that decreased. Goudjil et al. (2015) ${ }^{28}$ also confirmed the same results by studying the drying effect on the Laurus nobilis Lauraceae essential oil content.

On the other hand, Zrira et al. (1995) ${ }^{29}$ reported that during drying of $\mathrm{E}$. camaldulensis leaves under the shade. The essential oil yield increased by $54 \%$ (maximum reached the 16th day). According to them, this result is due to enzymatic activity and that the essential oil biosynthesis persists after the harvesting of the plant material because of water stress. Conversely to the EO yield, which has undergone a significant variation, the HY yield showed a lower variation $(0.2 \%-0.6 \%)$ (Figure 2$)$.

\subsection{Evolution of essential oil and hydrolat chemical composition}

As shown in Table 1, the GC-MS analyses of T. capitata (L.) Cav EO have identified ten volatile compounds representing 97.28 to $99.50 \%$ of total oil. It mostly consisted of phenolic monoterpene carvacrol during the process of plant drying (80.10\%-92.27\%) confirming that $T$. capitata (L.) $\mathrm{Cav}$ is a carvacrol chemotype, according to literature data for this species in the world ${ }^{30-33}$. Biogenetic precursors of the phenols were present in a $1.02 \%-4.81 \%$ range $p$-cymene and $0.24 \%-1.86 \%$ $\gamma$-terpinene along with $\alpha$-humulene $2.58 \%-4.67 \%$ as the only sesquiterpene constituent identified in this oil. Thus, linalool, as an oxygenated monoterpene was identified at relatively much lower levels $(0.80 \%-2.06 \%)$. Among others constituents detected in EO, many monoterpene hydrocarbons were found at very lower concentrations: $\alpha$-pinene $(0.36 \%-0.71 \%), \quad$ sabinene $\quad(0.42 \%-0.62 \%)$, $\beta$-phellandrene $\quad(0.45-0.90 \%), \quad \beta$-ocimene $(0.28 \%-0.78 \%)$ and terpinolene $(0.52 \%-0.86 \%)$. 


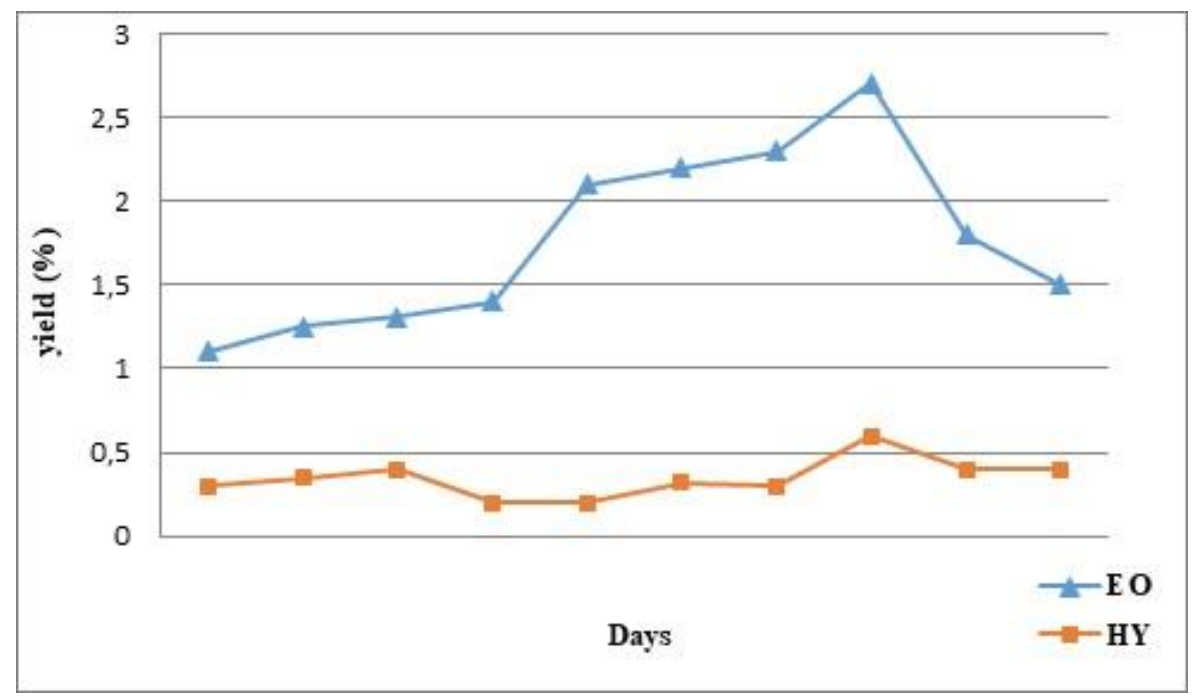

Figure 2. Evolution of T. capitata (L.) Cav essential oil and dissolved oil in hydrolat yield versus drying time (Days). Data are the mean of three determinations

The results summarized in Table 1 indicated likewise that drying time influenced the chemical composition of T. capitata (L.) significantly Cav, especially carvacrol, $p$-cymene, and $\gamma$-terpinene. Thus, the concentration of carvacrol changed, unlike that of $p$ cymene, which may explain the biogenetic relationship between these constituents. Indeed, the metabolic pathway for the carvacrol formation begins with the unsaturation, followed by the hydroxylation to C-2 aromatic ring ${ }^{32}$ (Figure 3).
This shows the critical role played by the $\gamma$-terpinene in the flavoring process and by $p$-cymene as a precursor for oxygenates compounds $34-35$. On the other hand, our results are in harmony with those of Silou et al. (2002) ${ }^{36}$ and Bourkhiss et al. (2009) ${ }^{27}$ who reported that drying time influences the chemical composition of Eucalyptus citriodora and Tetraclinis articulata (Vahl) Masters essential oil respectively, and especially the main components.
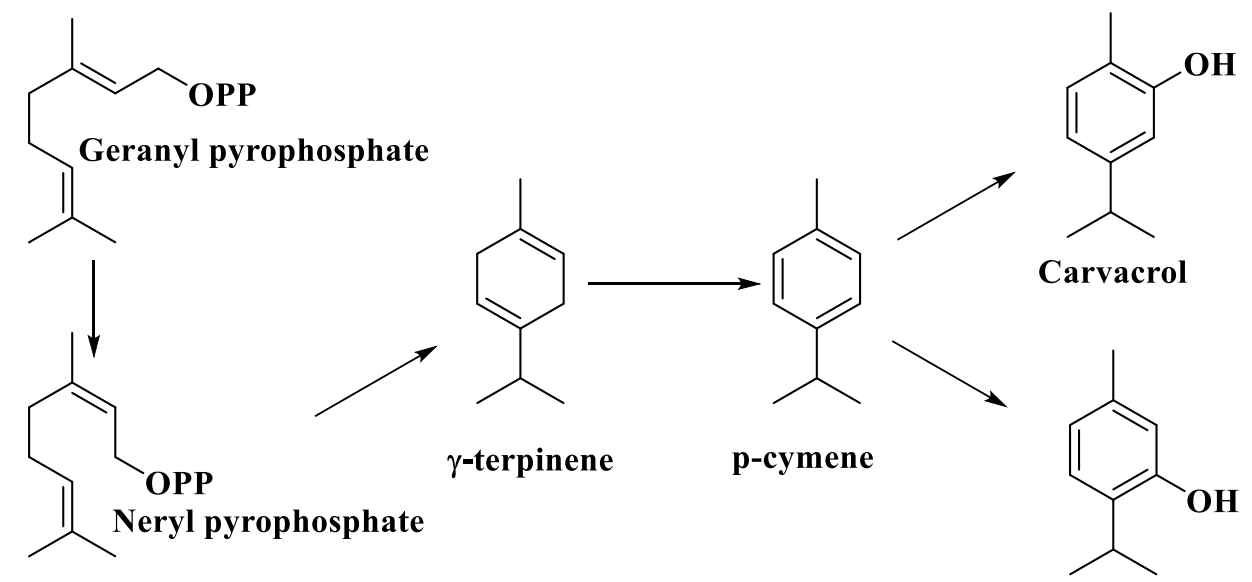

Thymol

Figure 3. General biosynthesis pathways of aromatic monoterpenes carvacrol and thymol

A total of seven components were identified, amounting to $98.44 \%-100 \%$ of the T. capitata (L.) $\mathrm{Cav}$ hydrolat (HY) during the plant drying process. This extract was constituted mainly of carvacrol (94.67\%-98.42\%) along with $\alpha$-humulene at much lower concentrations $(0.31 \%-0.86 \%)$. It was likewise characterized by the absence or almost absence of monoterpene hydrocarbons owing to their lipophilic character. Generally, the oxygenated constituents are found in large quantities in hydrolat because of their hydrophilic character. In contrast, the lipophilic terpene compounds are absent or almost absent, which is by other studies ${ }^{32,33,37}$. On the other hand, acetovanillone acetate, as an oxygenated derivative not detected in EO, was present in HY $(0.2 \%-1.80 \%)$.

Based on the data obtained in this work (Table 1), the highest proportion of carvacrol $(92.27 \%)$ was observed in EO on the $5^{\text {th }}$ day of drying plant, while this compound recorded utmost concentration in $\mathrm{HY}$ on the $7^{\text {th }}$ day $(98.42 \%)$. 
Table 1. Chemical composition of EO and HY from T. capitata (L.) Cav during plant.

Concentration \%

\begin{tabular}{|c|c|c|c|c|c|c|c|c|c|c|c|c|c|c|c|c|c|c|c|c|c|c|c|}
\hline \multirow[t]{2}{*}{ RT } & \multirow[t]{2}{*}{ RI } & \multirow[t]{2}{*}{ LRI } & \multirow[t]{2}{*}{ Compounds } & \multicolumn{10}{|c|}{ Essential oils (EO) } & \multicolumn{10}{|c|}{ Hydrolats (HY) } \\
\hline & & & & $\mathbf{E O}_{1}$ & $\mathrm{EO}_{2}$ & $\mathrm{EO}_{3}$ & $\mathrm{EO}_{4}$ & $\mathbf{E O}_{5}$ & $\mathbf{E O}_{6}$ & $\mathbf{E O}_{7}$ & $\mathbf{E O}_{8}$ & EO$_{9}$ & $\mathbf{E O}_{10}$ & $\mathbf{H Y}_{1}$ & $\mathrm{HY}_{2}$ & $\mathbf{H Y}_{3}$ & $\mathrm{HY}_{4}$ & $\mathbf{H Y}_{5}$ & $\mathrm{HY}_{6}$ & $\mathbf{H Y}_{7}$ & $\mathrm{HY}_{8}$ & $\mathrm{HY}_{9}$ & $\mathrm{HY}_{10}$ \\
\hline \multicolumn{24}{|c|}{ Monoterpene hydrocarbons } \\
\hline 7.28 & 931 & 939 & $\alpha$-Pinene & $\operatorname{tr}$ & $\operatorname{tr}$ & $\operatorname{tr}$ & 0,42 & $\operatorname{tr}$ & 0.36 & 0,71 & $\operatorname{tr}$ & 0.48 & 0.45 & $\operatorname{tr}$ & $\operatorname{tr}$ & $\operatorname{tr}$ & $\operatorname{tr}$ & $\operatorname{tr}$ & $\operatorname{tr}$ & $\operatorname{tr}$ & $\operatorname{tr}$ & $\operatorname{tr}$ & $\operatorname{tr}$ \\
\hline 8.43 & 969 & 975 & Sabinene & $\operatorname{tr}$ & 0.52 & $\operatorname{Tr}$ & 0,62 & 0.58 & 0.61 & 0,47 & 0,42 & 0,45 & 0.48 & $\operatorname{tr}$ & $\operatorname{tr}$ & $\operatorname{tr}$ & 0,39 & $\operatorname{tr}$ & $\operatorname{tr}$ & $\operatorname{tr}$ & 0,19 & $\operatorname{tr}$ & $\operatorname{tr}$ \\
\hline 9.15 & 1023 & 1025 & $p$-Cymene & 3.08 & 3.12 & 3.21 & 4,81 & 1,02 & 7.02 & 5,44 & 3,36 & 3,02 & 3.11 & 0.31 & 0.33 & 0,34 & 1,15 & 0,44 & 0,30 & 0,37 & 0,67 & 0,55 & 0.57 \\
\hline 9.50 & 1031 & 1031 & $\beta$-Phellandrene & 0.46 & 0.43 & 0.48 & 0.45 & $\operatorname{tr}$ & 0.78 & 0.90 & 0.58 & 0.51 & 0.53 & $\operatorname{tr}$ & $\operatorname{tr}$ & $\operatorname{tr}$ & $\operatorname{tr}$ & $\operatorname{tr}$ & $\operatorname{tr}$ & $\operatorname{tr}$ & $\operatorname{tr}$ & $\operatorname{tr}$ & $\operatorname{tr}$ \\
\hline 9.74 & 1034 & 1037 & $\beta$-Ocimene & 0.33 & 0.35 & 0.39 & 0.28 & $\operatorname{tr}$ & 0.78 & 0.42 & 0.26 & 0.41 & 0.43 & $\operatorname{tr}$ & $\operatorname{tr}$ & $\operatorname{tr}$ & $\operatorname{tr}$ & $\operatorname{tr}$ & $\operatorname{tr}$ & $\operatorname{tr}$ & $\operatorname{tr}$ & $\operatorname{tr}$ & $\operatorname{tr}$ \\
\hline 10.70 & 1056 & 1062 & $\gamma$-Terpinene & 1.55 & 1.53 & 1.51 & 1.27 & 0.24 & 1.70 & 1.86 & 1.59 & 1.55 & 1.52 & $\operatorname{tr}$ & $\operatorname{tr}$ & $\operatorname{tr}$ & 0.38 & $\operatorname{tr}$ & $\operatorname{tr}$ & $\operatorname{tr}$ & 0.18 & $\operatorname{tr}$ & $\operatorname{tr}$ \\
\hline 10.90 & 1083 & 1088 & Terpinolene & 0.51 & 0.55 & 0.52 & 0.53 & $\operatorname{tr}$ & 0.86 & 0.80 & 0.61 & 0.55 & 0.52 & $\operatorname{tr}$ & $\operatorname{tr}$ & $\operatorname{tr}$ & $\operatorname{tr}$ & $\operatorname{tr}$ & $\operatorname{tr}$ & $\operatorname{tr}$ & $\operatorname{tr}$ & $\operatorname{tr}$ & $\operatorname{tr}$ \\
\hline \multicolumn{24}{|c|}{ Oxygenated monoterpenes } \\
\hline 10.95 & 1101 & 1098 & Linalool & 1.25 & 1.21 & 1.21 & 2.04 & 1.84 & 2.06 & 1.55 & 0.91 & 0.80 & 0.83 & 0.55 & 0.61 & 0.67 & 1.28 & 0.56 & 0.41 & 0.53 & 0.60 & 0.43 & 0.38 \\
\hline 17.49 & 1300 & 1298 & Carvacrol & 86.78 & 86.74 & 86.66 & 85.23 & 92.27 & 80.10 & 83.56 & 87.01 & 87.50 & 87.41 & 97.51 & 97.47 & 97.48 & 94.67 & 97.23 & 97.14 & 98.42 & 96.73 & 96.85 & 96.83 \\
\hline \multicolumn{24}{|c|}{ Sesquiterpene hydrocarbons } \\
\hline 20.69 & 1451 & 1454 & $\alpha$-Humulene & 2.85 & 2.89 & 2.92 & 3.60 & 3.55 & 4.67 & 3.54 & 2.62 & 2.58 & 2.61 & 0.47 & 0.37 & 0.36 & 0.86 & 0.31 & 0.35 & 0.34 & 0.48 & 0.41 & 0.46 \\
\hline \multicolumn{24}{|c|}{ Oxygenated derivatives } \\
\hline 21.26 & 1570 & 1573 & $\begin{array}{c}\text { Acetovanillone } \\
\text { acetate }\end{array}$ & $\operatorname{tr}$ & $\operatorname{tr}$ & $\operatorname{tr}$ & $\operatorname{tr}$ & $\operatorname{tr}$ & $\operatorname{tr}$ & $\operatorname{tr}$ & $\operatorname{tr}$ & $\operatorname{tr}$ & $\operatorname{tr}$ & 1.12 & 1.20 & 1.14 & 1.26 & 1.45 & 1.80 & 0.34 & 0.27 & 0.20 & 1.25 \\
\hline \multicolumn{4}{|c|}{ Monoterpene hydrocarbons } & 5.93 & 6.50 & 6.11 & 8.38 & 1.84 & 12.11 & 10.60 & 6.82 & 6.97 & 7.04 & 0.31 & 0.33 & 0.34 & 1.92 & 0.44 & 0.30 & 0.37 & 1.04 & 0.55 & 0.57 \\
\hline \multicolumn{4}{|c|}{ Oxygenated monoterpenes } & 88.03 & 87.95 & 87.87 & 87.27 & 94.11 & 82.16 & 85.11 & 87.92 & 88.32 & 88.24 & 98.06 & 98.08 & 98.15 & 95.95 & 97.79 & 97.55 & 98.95 & 97.33 & 97.28 & 97.21 \\
\hline \multicolumn{4}{|c|}{ Sesquiterpene hydrocarbons } & 2.85 & 2.89 & 2.92 & 3.60 & 3.55 & 4.67 & 3.54 & 2.62 & 2.52 & 2.61 & 0.47 & 0.37 & 0.36 & 0.86 & 0.31 & 0.35 & 0.34 & 0.48 & 0.41 & 0.46 \\
\hline \multicolumn{4}{|c|}{ Oxygenated derivatives } & $\operatorname{tr}$ & $\operatorname{tr}$ & $\operatorname{tr}$ & $\operatorname{tr}$ & $\operatorname{tr}$ & $\operatorname{tr}$ & $\operatorname{tr}$ & $\operatorname{tr}$ & $\operatorname{tr}$ & $\operatorname{tr}$ & 1.12 & 1.20 & 1.14 & 1.26 & 1.45 & 1.80 & 0.34 & 0.27 & 0.20 & 1.25 \\
\hline \multicolumn{4}{|c|}{ Total \% } & 96.81 & 97.34 & 96.90 & 99.25 & 99.50 & 98.94 & 99.25 & 97.36 & 97.81 & 97.89 & 99.96 & 99.98 & 99.99 & 99.99 & 99.99 & 100 & 100 & 99.12 & 98.44 & 99.49 \\
\hline
\end{tabular}

tr: Trace $(\geq 0.17)$

RI: Retention indices as determined on DB-5MS column using homologous series of n-alkanes

LRI: Literature retention indices on DB-5MS column

RT: Retention times 


\section{Conclusion}

Our findings have shown that the highest yield in the hydro distillate $T$. capitata (L.) Cav EO was observed on the $8^{\text {th }}$ day of the plant drying process $(2.7 \%)$. Besides, the highest rate of carvacrol in EO was reached on the $5^{\text {th }}$ day of the plant drying process $(92.27 \%$ ), while HY recovered on the 7 th day shown carvacrol in its highest concentration $(98.42 \%)$ which makes this oil as quasi-pure product. On the economic plan, it is better to dry this plant for 8 days to reach maximum yield, while it is drying for 5 days provides a maximum concentration of the phenolic compound carvacrol as the active component of this plant.

\section{Acknowledgments}

This research did not receive any specific grant from funding agencies in the public, commercial, or notfor-profit sectors.

\section{Experimental}

\subsection{Plant material}

The aerial parts of $T$. capitata (L.) Cav. $(11 \mathrm{~kg})$ was collected at the flowering stage in July 2015 from the Tetouan area in northern Morocco (Latitude: $35^{\circ} 34^{\prime} 42^{\prime \prime} \mathrm{N}$, Longitude: $5^{\circ} 22^{\prime} 06^{\prime \prime} \mathrm{W}$; at $121 \mathrm{~m}$ above sea level). The identification of this plant was confirmed by Professor Mohamed Kadiri (botanist in Biology Department, Faculty of Sciences, Tetouan, Morocco). The voucher specimen (INP 1235) was deposited in the herbarium of the national institute of medicinal and aromatic plants of Taounate in the Sidi Mohamed Ben Abdellah University Fes Morocco. Ten (10) samples were air-dried at room temperature under shade until the weight was stable.

\subsection{Isolation of essential oil and dissolved oil in hydrolat}

After plant harvesting, a series of 10 samples of $500 \mathrm{~g}$ were weighed and subjected to hydrodistillation for $3 \mathrm{~h}$ (dried with an interval of 24h) using a Clevengertype apparatus advocated by the European Pharmacopoeia that allows the recycling of the aqueous phase of the distillate using a cohobage system. Essential oils then dissociate spontaneously of hydrolats for their immiscibility. The dissolved oil in hydrolat was obtained by liquid-liquid extraction of hydrolat from each hydrodistillation with dichloromethane $\left(\mathrm{CH}_{2} \mathrm{Cl}_{2}\right)^{38}$. The organic phase was evaporated under reduced pressure by a rotary evaporator giving a yellowish extract. Three replicates were performed for each sample, and the recovered oils each day were combined and named from $\mathrm{EO}_{1}$ to $\mathrm{EO}_{10}$. The same for corresponding hydrolats witch named from $\mathrm{HY}_{1}$ to $\mathrm{HY}_{10}$. Finally, all oils were dried with $\mathrm{Na}_{2} \mathrm{SO}_{4}$ and stored in the tightly closed dark vial at $4^{\circ} \mathrm{C}$ until analysis.

\subsection{Chromatographic analysis}

The analysis of the essential oils and hydrolat extracts was performed on a GC-MS (Agilent Technologies, J\&W Scientific Products, Palo Alto, CA, USA), equipped with an Agilent Technologies capillary DB-5MS column (30 m length; $0.25 \mathrm{~mm}$ i.d.; $0.25 \mathrm{~mm}$ film thickness), and coupled to a mass selective detector (MSD5975B, ionization voltage $70 \mathrm{eV}$; all Agilent, Santa Clara, CA). The carrier gas was Helium and was used at $1 \mathrm{~mL} \mathrm{~min}{ }^{-1}$ flow rate. The oven temperature program was as follows: $1 \mathrm{~min}$ at $100^{\circ} \mathrm{C}$ ramped from 100 to $260^{\circ} \mathrm{C}$ at $4^{\circ} \mathrm{C} \mathrm{min}^{-1}$ and $10 \mathrm{~min}$ at $260^{\circ} \mathrm{C}$. The chromatograph was equipped with a split/splitless injector used in the split mode. The split ratio was 1:100. The identification of components was assigned by matching their mass spectra with Wiley and NIST library data and standards of the main components. After that, Kovats retention indices calculated by linear interpolation relative to retention times of $\mathrm{C}_{8} \mathrm{C}_{22} n$-alkanes ${ }^{39}$ were compared with reference libraries or literature data ${ }^{40}$ and with those of authentic compounds by their co-injection under the same chromatographic conditions mentioned above. Quantification was done by the standard external method using calibration curves generated by running GC analysis of authentic representative compounds. All compounds concentrations less than $0.17 \%$ are considered as traces.

\section{References}

1- S. M. Albano, M. G. Miguel, Biological activities of extracts of plants grown in Portugal, Industrial Crops and Products, 2011, 33(2), 338-343.

2- E. P. Gutiérrez-Grijalva, M. A. Picos-Salas, N. Leyva-López, M. S. Criollo-Mendoza, G. Vazquez-Olivo, J. B. Heredia, Flavonoids and phenolic acids from oregano: occurrence, biological activity and health benefits, Plants, 2018, 7, 2.

3- A. Bouyahya, J. Abrini, A. Et-Touys, Y. Bakri, N. Dakka, Indigenous knowledge of the use of medicinal plants in the North West of Morocco and their biological activities, Eur. J. Integr. Med., 2017, 13, 9-25.

4- A. Aghraz, J. Wanner, E. Schmidt, L. Aitdra, M. Aitsidibrahim, N. Tabanca, A. Ali, A. Nafis, L. Hassani, M. Markouk, L. Jirovetz, M. Larhsini, Chemical composition, in vitro antioxidant, antimicrobial and insecticidal activities of essential oil from Cladanthus arabicus , J. Essent. Oil Bear. Plants, 2017, 20, 601-609.

5- M. Hazzit, A. Baaliouamer, A. R. Veríssimo, M. L. Faleiro, M. G. Miguel, Chemical composition and biological activities of Algerian Thymus oils, Food chem., 2009, 116, 714-721.

6- A. Benabid, Flore et écosystème du Maroc, Evaluation et préservation de la biodiversité ; ed. Ibis Press ; Paris France, 2000, 159-161. 
7- E. Stahl-Biskup, F. Saez, Thyme - The Genus Thymus; Taylor \& Francis, London, 2002.

8- M. G. Miguel, Antioxidant and antiinflammatory activities of essential oils: a short review, Molecules, 2010, 15, 9252-9287.

9- H. N. Badi, D. Yazdani, S. M. Ali, N. Fatemeh, Effects of spacing and harvesting time on herbage yield and quality/quantity of oil in thyme, Thymus vulgaris L., Ind Crops Prod., 2004, 19, 231-236

10-M. Babaei, M. E. Abarghoei, R. Ansari, A. A. Vafaei, A. A. Taherian, M. M. Akhavan, T. J. Alaavi, S. Mousavi, Antispasmodic effect of hydroalcoholic extract of Thymus vulgaris on the guinea-pig ileum, Nat. Prod. Res., 2008, 22, 1143-1150.

11-C. Ballester-Costa, E. Sendra, J. FernándezLópez, J. A. Pérez-Álvarez, M. Viuda-Martos, Assessment of antioxidant and antibacterial properties on meat homogenates of essential oils obtained from four Thymus species achieved from organic growth, Foods, 2017, 6, 59.

12-M. Šegvić Klarić, I. Kosalec, J. Mastelić, E. Pieckova, S. Pepeljnak, Antifungal activity of thyme (Thymus vulgaris L.) essential oil and thymol against moulds from damp dwellings, Lett Appl Microbiol., 2007, 44, 36-42.

13-K. S. De Lira Mota, F. De Oliveira Pereira, W. A. De Oliveira, I. O. Lima, E. De Oliveira Lima, Antifungal activity of Thymus vulgaris L. essential oil and its constituent phytochemicals against Rhizopus oryzae: interaction with ergosterol, Molecules, 2012, 17, 14418-14433.

14-E. A. Carlini, E. Rodrigues, F. R. Mendes, R. Tabach, B. Gianfratti, Treatment of drug dependence with Brazilian herbal medicines, Rev Bras Farmacogn., 2006, 16, 690-695.

15-M. Mahboubi, R. Heidarytabar, E. Mahdizadeh, H. Hosseini, Antimicrobial activity and chemical composition of Thymus species and Zataria multiflora essential oils. Agriculture and Natural Resources, Agric. Nat. Resour., 2017, 51, 395-401.

16-A. C. Figueiredo, J. G. Barroso, L. G. Pedro, L. Salgueiro, M. G. Miguel, M. L. Faleiro, Portuguese Thymbra and Thymus species volatiles: Chemical composition and biological activities, Curr. Pharm. Des., 2008, 14, 3120-3140.

17-A. D. Mohammed, M. G. Miguel, M. D. Antunes, A. C. Figueiredo, L. G. Pedro, J. G. Barroso, Antioxidant activity of Thymbra capitata essential oil in meat-treated oil, Acta Hortic., 2010, 853, 319-322.

18-A. Jayari, N. El Abed, A. Jouini, O. Mohammed Saed Abdul-Wahab, A. Maaroufi, S. Ben Hadj Ahmed, Antibacterial activity of Thymus capitatus and Thymus algeriensis essential oils against four food-borne pathogens inoculated in minced beef meat, J Food Saf, 2018, 38, e12409.

19-M. G. Mkaddem, M. Romdhane, H. Ibrahim,
M. Ennajar, A. Lebrihi, F. Mathieu, J. Bouajila, Essential oil of Thymus capitatus Hoff. et Link. from matmata, Tunisia: gas chromatographymass spectrometry analysis and antimicrobial and antioxidant Activities, J. Med. Food, 2010, 13, 1500-1504.

20-S. B. H. Ahmed, R. M. Sghaier, F. Guesmi, B. Kaabi, M. Mejri, H. Attia, D. Laouini, I. Smaali, Evaluation of antileishmanial, cytotoxic and antioxidant activities of essential oils extracted from plants issued from the leishmaniasis-endemic region of Sned (Tunisia), Nat. Prod. Res., 2011, 25, 1195-1201.

21-I. B. E. H. Ali, M. Chaouachi, R. Bahri, I. Chaieb, M. Boussaïd, F. Harzallah-Skhiri, Chemical composition and antioxidant, antibacterial, allelopathic and insecticidal activities of essential oil of Thymus algeriensis Boiss et Reut, Ind Crops Prod, 2015, 77, 631-639

22-N. El Abed, B. Kaabi, M. I. Smaali, M. Chabbouh, K. Habibi, M. Mejri, A. S. Ben Hadj, Chemical composition, antioxidant and antimicrobial activities of Thymus capitata essential oil with its preservative effect against Listeria monocytogenes inoculated in minced beef meat, Evid. Based Complementary Altern. Med., 2014, 1-11.

23-A. P. De Oliveira, R. P. De-Oliveira, C. Gaspar, L. Salgueiro, C. Cavaleiro, J. M. De-Oliveira, J. A. Queiroza, A. G. Rodrigues, Association of Thymbra capitata essential oil and chitosan (TCCH hydrogel): A putative therapeutic tool for the treatment of vulvovaginal candidosis , Flavour Frag. J., 2013, 28, 354-359.

24-S. Al-Qura'n, Ethnopharmacological survey of wild medicinal plants in Showbak, Jordan, J. Ethnopharmacol., 2009, 123, 45-50.

25-T. Antal, A. Figiel, B. Kerekes, L. Sikolya, Effect of drying methods on the quality of the essential oil of spearmint leaves (Mentha spicata L.), Dry. Technol., 2011, 29, 1836-1844.

26-A. Figiel, A. Szumny, A. Gutierrez-Ortiz, A. Carbonell-Barrachina, Composition of oregano essential oil (Origanum vulgare) as affected by drying method, J. Food Eng., 2010, 98, 240-247.

27-M. Bourkhiss, B. M. Hnach, Bourkhiss, M. Ouhssine, A. Chaouch, B. Satrani, Drying effect on content and chemical composition of Tetraclinis articulata (Vahl) Masters essential oils, Agrosolutions, 2009, 20, 44-48.

28-M. B. Goudjil, S. E. Bencheikh, S. Zighmi, S. Ladjel, Détermination expérimentale de la cinétique de séchage à l'ombre des huiles essentielles de laurus nobilis Lauraceae, Annales des Sciences et Technologie, 2015, 7, 53-57.

29-S. Zrira, B. Benjilali, G. Lamaty, Effet du séchage à l'air libre des feuilles d'E. camaldulensis sur le rendement et la composition de l'huile essentielle, Actes Inst. Agron. Vet., 1995, 15, 27-35. 
30-S. Bounatirou, S. Smiti, M. G. Miguel, L. Faleiro, M. N. Rejeb, M. Neffati, M. M. Costa, A. C. Figueiredo, J. G. Barroso, L. G. Pedro, Chemical composition, antioxidant and antibacterial activities of the essential oils isolated from Tunisian Thymus capitatus Hoff. Et Link., Food Chem. J., 2007, 105, 146-155.

31-F. Amarti, B. Satrani, M. Ghanmi, A. Aafi, A. Farah, L. Aarab, M. El Ajjouri, A. Guedira, A. Chaouch, Activité antioxydante et composition chimique des huiles essentielles de quatre espèces de thym du Maroc, Acta Bot. Gall., 2011, 158, 513-523.

32-A. Moukhles, S. Charfi, S. Zantar, L. Toukour, A. Ibn Mansour, Seasonal variation in yield and chemical composition of Moroccan Thymbra capitata (L) Cav. essential oil and its corresponding hydrolat extracted essential oil, Mor. J. Chem., 2019, 7, 246-253.

33-A. Moukhles, A. Ibn Mansour, A. Ellaghdach, J. Abrini, Chemical composition and in vitro antibacterial activity of the pure essential oils and essential oils extracted from their corresponding hydrolats from different wild varieties of Moroccan thyme, J Mater Environ Sci., 2018, 9, 235-244.

34-A. J. Poulose, R. Croteau, Biosynthesis of aromatic monoterpenes: Conversion of $\gamma$ terpinene to p-cymene and thymol in Thymus vulgaris L., Arch. Biochem. Biophys., 1978, 187, 307-314.

35-A. J. Poulose, R. Croteau, A key enzyme in the biosynthesis of aromatic monoterpenes, Arch. Biochem. Biophys., 1978, 191, 400-411.

36-T. Silou, F. Taty-loumbou, J. C. Chalchat, Etude de l'effet du séchage solaire sur le rendement et la composition chimique des huiles essentielles extraites des feuilles d'Eucalyptus citriodora, Ann. Fals. Exp. Chim., 2002, 960, 287-301.

37-L. Tabti, M. E. A. Dib, N. Djabou, N. G. Benyelles, J. Paolini, J. Costa, A. Muselli, control of fungal pathogens of «citrus sinensis L» by essential oil and hydrosol of thymus capitatus L., J Appl Bot Food Qual, 2014, 87, 279 - 285.

38-V. Jeannot, J. Chahboun, D. Russel, H. Casabianca, Origanum compactum Bentham: composition of the hydrolat aromatic fraction, comparison with the essential oil and its interest in aromatherapy, Int J Aromather., 2003, 13, 90-94.

39-H. Van Den Dool, P. D. Kratz, A generalization of the retention index system including linear temperature programmed gas-liquid partition chromatography, J. Chromatogr. A., 1963, 11, 463-471.

40-R. P. Adams, Identification of essential oil components by gas Chromatography/Mass Spectrometry; $4^{\text {th }}$ ed., Allured Pub., Carol Stream, IL, USA, 2007. 
